\title{
Prevalence of Diabetic Nephropathy among Type 2 Diabetes Mellitus, and Glycaemic Control Evaluated by Glycaeted Haemoglobin in Diabetic Patients with and without Diabetic Nephropathy
}

\author{
OSAM S. ABDO GABALI, M.D.; AHMED S.O. AL-GEFRI, M.D. and LINDA M.H. BAALWI, M.D.
}

The Department of Internal Medicine, Faculty of Medicine and Health Sciences, Aden University, Yemen

\begin{abstract}
Background: Diabetic Nephropathy (DN) is by far the most common cause of End-Stage Renal Disease (ESRD). Approximately one-third of individuals with diabetes develop DN, with a high likelihood of progression to ESRD. In addition, $\mathrm{DN}$ is associated with considerably increased cardiovascular disease risk and mortality.
\end{abstract}

Aim of Study: The purpose of this study is to determine the prevalence of diabetic nephropathy between T2DM, and glycaemic control evaluated by a glycaeted haemoglobin in diabetic patients with and without diabetic nephropathy.

Material and Methods: This study was carried out on 100 diabetic patients who attended a private clinic in Aden-Yemen. Over a period from 1 st June 2018 to 1 st January 2019. All the participants studied were subjected to assessment of sex, age and duration of diabetes with laboratory investigations including determination of urinary albumin to creatinine ratio, and glycated haemoglobin $\left(\mathrm{HbA}_{l_{\mathrm{c}}}\right)$.

Results: The results showed that $14 \%$ of all patients have been studied had diabetic nephropathy, there were statistically significant relationships between diabetic nephropathy and duration of diabetes $(p=0.040)$, there were no statistically significant relationships between diabetic nephropathy and age, sex and glycated haemoglobin level $\left(\mathrm{HbA}_{l_{\mathrm{c}}}\right)$ of the patients.

Conclusion: Screening for microalbuminuria will enable early identification of patients with DN. Duration of DM and was strong predictor associated with the development of DN in the patients studied.

This also raises a red flag against the common medical practice of only using Serum Creatinine as a test to determine renal function.

Key Words: Diabetic nephropathy - T2DM - HBA $1 C$.

Correspondence to: Dr. Osam S. Abdo Gabali, The Department of Internal Medicine, Faculty of Medicine and Health Sciences, Aden University, Yemen

\section{Introduction}

DIABETES Mellitus (DM) is a metabolic disorder characterized by persistence hyperglycaemia resulting from the defects in insulin secretion, action or both. Diabetes mellitus is not a single disease but a group of several metabolic disorders, which shares a common feature of hyperglycaemia [1]

$\mathrm{DM}$ is the leading cause of End Stage Renal Disease (ESRD). Although both type 1 and type 2 DM can lead to ESRD, the majority of patients are those with type $2 \mathrm{DM}$ [2].

In the Middle East, diabetes is also prevalent, mirroring the current global epidemic of diabetes [3]. The high prevalence of obesity and lack of exercise, along with the possibility of regionspecific genetic mutation associated with diabetes, may be the explanation, thereby further confirming the genetic peculiarity of some populations $[4,5]$.

Type 2 diabetes mellitus is one of the major chronic disease burdens with a prevalence of 422 million patients worldwide [6]. Type 2 diabetes is expected to be the seventh most common cause of death in the world by 2030 , primarily due to its rapid rise in middle-income and low-income countries [7].

Complications of diabetes contribute greatly to the increased mortality and morbidity associated with this disease. Diabetic complications are customarily divided into two main categories: Macrovascular complications, including heart disease and stroke, and microvascular complications, which include retinopathy, nephropathy, and neuropathy, 
microvascular complications accounted for about half the total number of complications [8].

Diabetic Nephropathy (DN), which is characterized by proteinuria, is one of the most serious long-term microvascular complications of DM. The proportion of $\mathrm{DN}$ is increasing worldwide. DN is the leading cause of chronic kidney diseases and end-stage renal disease, which constitutes the major workload of dialysis centres worldwide. Microalbuminuria (MA) is the earliest sign of DN, so the early detection of MA and early control of diabetes retards the progression of DN [9].

Diabetic nephropathy and microalbuminuria are also strong predictors of cardiovascular and overall morbidity and mortality in patients of diabetes, and hence vital indicators in the patients [10].

Diabetic nephropathy is a progressive kidney disease involving damage to the capillaries in the kidneys' glomeruli because of longstanding DM, characterized by diffuse scarring of the glomeruli. While final diagnosis may need a biopsy, diagnosis is usually done with measurement of urinary albu$\mathrm{min} / \mathrm{GFR} /$ creatinine clearance/serum creatinine levels [11]

\section{Material and Methods}

This was a prospective study carried out in a private clinic in Aden-Yemen, included 100 patients with type 2 diabetes mellitus and age of 30 years old or more, over a period from ${ }^{1 \mathrm{se}}$ June 2018 to 1 st January 2019.

The participants divided into those with diabetic nephropathy, and those without.

Inclusion criteria: Local Yemeni patient with age 30 years or more and type 2 diabetes mellitus.

Exclusion criteria: Included subjects less than 30 years of age, subjects diagnosed with type I diabetes, hypertensive patients, users of medications affecting kidney and those with gestational diabetes.

All participants were subjected to laboratory investigations including:

1- Random urine samples were collected for determination of creatinine and microalbumin in urine to calculate the albumin/creatinine ratio.

2- A blood sample was placed in an EDTA tube for quantitative colorimetric determination of $\mathrm{HbA}_{l_{\mathrm{c}}}$
Diabetes was diagnosed based on ADA criteria: Fasting blood sugar of $126 \mathrm{mg} / \mathrm{dl}$ or more and random blood sugar of $200 \mathrm{mg} / \mathrm{dl}$ or more or Glycated haemoglobin $6.5 \%$ or more [12]

Nephropathy was defined as 30-299mcg of albumin/mg of creatinine, for microalbuminuria and $>300 \mathrm{mcg}$ of albumin $/ \mathrm{mg}$ of creatinine for macroalbuminuria in two of the three tests within 3-6 months [9]

Degree of glycaemic control was determined by Glycated haemoglobin $\left(\mathrm{Hba}_{1_{\mathrm{c}}}\right)$.

It was divided into good control: Hba $_{1 \mathrm{c}}<7 \%$ and poor control: $\mathrm{Hba}_{1 \mathrm{c}}>9 \%$.

Ethical consideration: Verbal informed consent was obtained from all participating subjects. The research and ethics committee in the Faculty of Medicine University of Aden approved the study design.

Data analysis was done using statistical package for social science software for windows (SPSS) Version 20. Results were presented as percentages and tables as appropriate.

$p$-value $<0.05$ considered to indicate the level of significance in the study.

\section{Results}

This study included 100 patients with type 2 diabetes mellitus, managed in a private clinic during the study period from 1 st June 2018 to ${ }^{1 \text { st }}$ January 2019.

The mean age of the patients recruited in this study was $54.09( \pm 8.4)$, it ranges from 30 to 67 years, the mean of diabetes duration among the study population was $8.28( \pm 6.59)$, $\mathrm{HBA}_{1 \mathrm{C}}$ mean value among recruited patients was $8.69( \pm 1.61)$.

14 patients had diabetic nephropathy, number of males and females diabetic nephropathy patients was equal $(50 \%)$ with ( $p$-value 1.00$)$ not statistically significant.

The peak prevalence of type 2 diabetic patients with nephropathy attending the private clinic during the study period was in the age group of 46-60 years $(64.2 \%)$, followed by the age group $>60$ years $(35.7 \%)$, it was statistically not significant ( $p$-value 0.285).

The majority of diabetic nephropathy patients were having T2DM in duration between 11-20 years $(57 \%)$ followed by $(21.4 \%)$ for those who 
have T2DM in duration of 5-10 years, which was statistically significant ( $p$-value 0.04).

Diabetic patients with nephropathy and poor controlled HBA1C was $(92.9 \%)$, while those with good control $(7.1 \%)$, it was not statistically significant ( $p$-value 0.330$)$.

Diabetic patients without nephropathy constitute $(82.6 \%)$, and (17.4\%) for those with poor controlled diabetes and good controlled diabetes respectively.

Table (1): Prevalence of Diabetic Nephropathy (DN) among type $2 \mathrm{DM}$.

\begin{tabular}{lcc}
\hline & No of patients & $\%$ \\
\hline Type 2 DM with DN & 14 & 100 \\
Type 2 DM without DN & 86 & 86 \\
\hline Total & 100 & 100 \\
\hline
\end{tabular}

Table (2): Sex distribution among type 2 DM with Diabetic Nephropathy (DN).

\begin{tabular}{lcc}
\hline Sex & No of patients & $\%$ \\
\hline Female & 7 & 50 \\
Male & 7 & 50 \\
\hline Total & 14 & 100 \\
\hline$p$-value $(1.00)$ & &
\end{tabular}

Table (3): Age distribution among type 2 DM with Diabetic Nephropathy (DN).

\begin{tabular}{lcl}
\hline Age group & No of patients & $\%$ \\
\hline $30-45$ & 0 & 0 \\
$46-60$ & 9 & 64.2 \\
$>60$ & 5 & 35.7 \\
\hline Total & 14 & 100 \\
\hline$p$-value $(0.285)$ & &
\end{tabular}

Table (4): Duration of DM among type 2 DM with Diabetic Nephropathy (DN).

\begin{tabular}{lcl}
\hline Duration of DM & No of patients & $\%$ \\
\hline <5 years & 2 & 14.2 \\
5-10 years & 3 & 21.4 \\
11-20 years & 8 & 57 \\
$>$ 20 years & 1 & 7.1 \\
\hline Total & 14 & 100 \\
\hline$p$-value $(0.040)$ &
\end{tabular}

Table (5): HBA $_{1 \mathrm{C}}$ among diabetics with diabetic nephropathy and without diabetic nephropathy.

\begin{tabular}{llllll}
\hline $\begin{array}{l}\text { Glycaemic control } \\
\text { HBA }_{1 \mathrm{C}}\end{array}$ & \multicolumn{2}{c}{$\begin{array}{c}\text { DM with } \\
\text { albuminuria }\end{array}$} & \multicolumn{2}{c}{$\begin{array}{c}\text { DM without } \\
\text { albuminuria }\end{array}$} & $\begin{array}{c}p \text { - } \\
\text { value }\end{array}$ \\
\hline Good control & 1 & $7.1 \%$ & 15 & $17.4 \%$ & 0.330 \\
Poor control & 13 & $92.9 \%$ & 71 & $82.6 \%$ & \\
\hline
\end{tabular}

\section{Discussion}

Among 100 patients have been recruited in the study, diabetic patients with nephropathy was $(14 \%)$. Near to $(15.3 \%)$ mentioned in the the study of Sohaila Cheema et al. [13]

Less than the results presented in the study made by Rahim MA et al., in Bangladesh, where diabetics with Nephropathy constitute (54.5\%) [14]

In addition, less than the results mentioned by Patel V et al., in their study, where total of 43 patients out of 100 patients were detected to have Diabetic Nephropathy [10].

Our study showed no statistically significant relationships between diabetic nephropathy and sex ( $p$-value 1.00), sex difference among diabetic nephropathy patients was equal $(50 \%)$.

While in the study made by Jiji Inassi1, Vijayalakshmy R among 120 diabetics with nephropathy, female patients with diabetic nephropathy was $(41.6 \%)$, while male $(58.3 \%)$ [15]

Also in the study made in El-Mahalla General Hospital, there were no statistically significant relationships between diabetic nephropathy and sex of the patient [16].

(64.2\%) of diabetics with diabetic nephropathy were (46-60) and $(35.7 \%)$ of patients were more than 60 years, there were no statistically significant relationships between diabetic nephropathy and age of the patient, similar to the study done in ElMahalla General Hospital [16].

The present study confirmed occurrence of albuminuria with increasing duration of diabetes; there was statistically significant relationship between duration of diabetes and nephrogenic diabetes.

Nine patients out of fourteen patients with nephrogenic diabetes had diabetes more than 10 years.

It was significantly higher among the group of patients with diabetes between $11-20$ years ( $p=$ 0.04).

Baig et al., studied 60 patients to compare duration of T2DM with micro albumin, concluded that in patients with T2DM and long duration of diabetes, significantly correlated with high level of microalbumin [17]. 
Duration of diabetes is an independent risk factor for DN and this is in agreement with other related studies $[\mathbf{1 8 , 1 9 ]}$.

In the present study, there were relationship between nephrogenic diabetes and poor glycaemic control. $\mathrm{HbA}_{1 \mathrm{c}}$ was higher among the patients in the group with DN than the patients in the group without DN but it was not statistically significant. ( $p$-value 0.33 ).

This relationship also presented in a study made in Oman by Alrawahi et al., [20] .

In the previously mentioned Baig et al., study, concluded that in patients with T2DM, and poor glycaemic control (depicted by high $\mathrm{HbA}_{1 \mathrm{c}}$ level) significantly correlated with high level of microalbumin [17] .

\section{References}

1- KUMAR R., ABBAS A., FAUSTO N. and ASTER J.C., eds.: Robbins and Cotron "Pathologic basis of disease" 8th Ed. Saunders Elsevier Publishing Division, 934-5, 1131-46, 2010

2- DAMINOV B.T.: The effects of eprosartan mesylate and lercanidipine on reducing microalbuminuria. Int. J. Bio. Med., 3 (2): 70-3, 2013.

3- C.R. PULLINGER, I.D. GOLDHNE, S. TANYOLAÇ, et al.: "Evidence that an HMGA1 gene variant associates with type 2 diabetes, body mass index, and high-density lipoprotein cholesterol in a Hispanic-American population," Metabolic Syndrome and Related Disorders, Vol. 12, No. 1, pp. 25-30, 2014.

4- K.H.K. CHAN, Y.T. HUANG, Q. MENG, et al.: "Shared molecular pathways and gene networks for cardiovascular disease and type 2 diabetes mellitus in women across diverse ethnicities," Circulation Cardiovascular Genetics, Vol. 7, No. 6, pp. 911-9, 2014.

5- A. ZABETIAN, H.M. KELLI, J.B. ECHOUFFOTCHEUGUI, K.M.V. NARAYAN and M.K. ALI: "Diabetes in the Middle East and North Africa," Diabetes Research and Clinical Practice, Vol. 101, No. 2, pp. 106$22,2013$.

6- GINTER E. and SIMKO V.: Diabetes type 2 pandemic in 21 st century. Bratislavské Lekárske Listy, 111: 134-7, 2009.

7- SHAW J.E., SICREE R.A., ZIMMET P.Z., et al.: Global estimates of the prevalence of diabetes for 2010 and 2030. Diabetes Res. Clin. Pract., 87: 4-14, 2010.

8- L. LITWAK, S.Y. GOH, Z. HUSSEIN, R. MALEK, V. PRUSTY and M.E. KHAMSEH: "Prevalence of diabetes complications in people with type 2 diabetes mellitus and its association with baseline characteristics in the multinational A1chieve study," Diabetology and Metabolic Syndrome, Vol. 5, No. 1, p. 57, 2013.
9- ABDURRAHMAN ALDUKHAYEL: Prevalence of diabetic nephropathy among Type 2 diabetic patients in some of the Arab countries, Int. J. Health Sci. (Qassim), Jan.Mar., 11 (1): 1-4, 2017.

10- VITAN PATEL, MINAL SHASTRI*, NISHA GAUR, PRUTHA JINWALA and ABHISHEK Y. KADAM: A study in prevalence of diabetic nephropathy in recently detected cases of type 2 diabetes mellitus as evidenced by altered creatinine clearance, urinary albumin and serum creatinine, with special emphasis on hypertension, hypercholesterolemia and obesity, Int. J. Adv. Med., Apr., 5 (2): $351-5,2018$

11-VIAZZI F., LEONCINI G., CONTI N., TOMOLILLO C., GIACHERO G., VERCELLI M., et al.: Microalbuminuria is a predictor of chronic renal insufficiency in patients without diabetes and with hypertension: The MAGIC study. Clin. J. Am. Soc. Nephrol., 5: 1099-106, 2010.

12- American diabetic Association ADA Standards of medical care in diabetes-Classification and Diagnosis of Diabetes. Diabetes Care, Volume 39, (Supplement 1): S13-S22, 2016.

13- SOHAILA CHEEMA, PATRICK MAISONNEUVE, MAHMOUD ZIRIE, AMIN JAYYOUSI, HEKMAT ALROUH, AMIT ABRAHAM, SURA AL-SAMRAYE, ZIYAD MAHFOUD, IBRAHIM MOHAMMED AL-JANAHI, BUTHAINA IBRAHIM, ALBERT B. LOWENFELS and RAVINDER MAMTANI: Risk Factors for Microvascular Complications of Diabetes in a High-Risk Middle East Population, Journal of Diabetes Research Volume, Article ID 8964027, 7 pages, 2018.

14- MUHAMMAD ABDUR RAHIM, PALASH MITRA, HASNA FAHMIMA HAQUE, TASRINA SHAMNAZ SAMDANI, SHAHANA ZAMAN and KHWAJA NAZIM UDDIN: Prevalence of chronic kidney disease stages 35 among patients with type 2 diabetes mellitus in Bangladesh, IMC J. Med. Sci., 11 (1): 19-24, 2017.

15- JIJI INASSI and VIJAYALAKSMY R.: Role of duration of diabetes in the development of nephropathy in type 2 diabetic patients National journal of medical research/ Volume 3-Issue 1-Jan.-March, 2013.

16- MUSTAFA M. ELNAJJARA, ALAA EL-DIEN DAWOODA, MAHMUD ABU SALEMB, ZEINAB A. KASEMYB and OLA T. NOHMANC: Diabetic nephropathy among diabetic patients attending El-Mahalla General Hospital, Journal of the Egyptian Society of Nephrology and Transplantation, 16: 39-43, 2016.

17- BAIG J.A., ASIF N., SARFARAZ A. and ALAM J.M. Correlation of microalbuminuria with glycosylated haemoglobin $\left(\mathrm{Hba}_{1 \mathrm{c}}\right)$ and duration of type 2 diabetes mellitus (T2DM) in male and female patients. Middle East J. Sci. Res., 24 (9): 2900-3, 2016.

18- REMA M., PRADEEPA R., DEEPA M., SHANTHIRANI C.S. and DEEPA R.: American Diabetic Association Prevalence and risk factors of diabetic nephropathy in an urban South Indian population: The Chennai Urban Rural Epidemiology Study (CURES 45). Diabetes Care, 30: 2019-24, 2007.

19- MODEBE O. and MASOOMI M.A.: Microalbuminuria and associated factors in Bahraini patients with type 2 diabetes mellitus. Ann. Saudi Med., 20: 157-60, 2000. 
20- ABDUL HAKEEM HAMOOD ALRAWAHI, SYED GAUHAR A., RIZVI DAWOOD AL-RIAMI and ZAHER AL-ANQOODI: Prevalence and risk factors of diabetic nephropathy in Omani type 2 diabetes in Al-Dakhiliyah Region, Oman Medical Journal, Vol. 27, No. 3: 212-6, 2012.

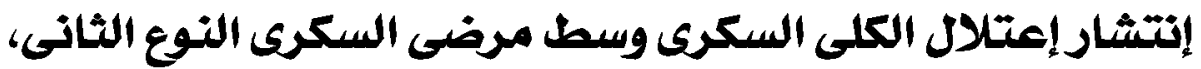

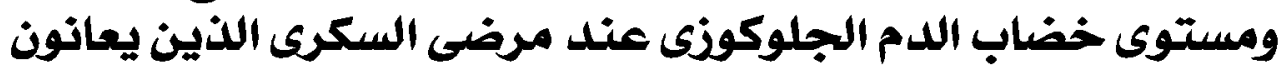

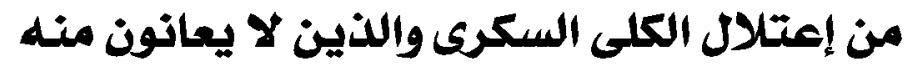

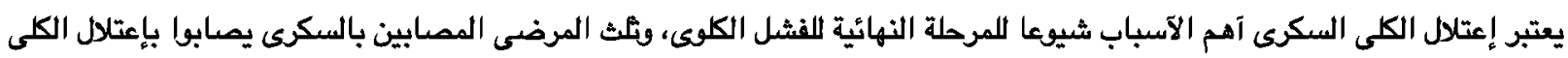
السكرى مع إحتمالية عالية آن يتطود المرض إلى المرحلة النهائية اللفشل الكلوى. ويرتبط إعتلال الكى السكرى إرتباط وثيق بمخاطر آمراض القلب والآوعية الدموية والوفيات. الآهداف: دراسة إنتشار إعتلال الكلى السكرى وسط مرضى السكرى النوع الثانى، ومستوى خضاب الدم الجلوكونى عند مرضى السكرى

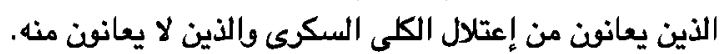

الآساليب: شملت الدراسة ـ ـ المريض من مرضى السكرى النوع الثانى، الذين حضروا لإحدى العيادات الخاصة فى علن-اليمن من الآل

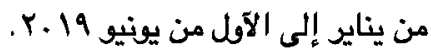

تم تحديد جنس وعمر المرضى، ومدة الإصابة بمرض السكرى، وعمل فحوصات لتقييم نسبة الزلال إلى الكرياتتين فى البول، ومستوى

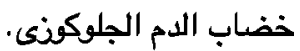

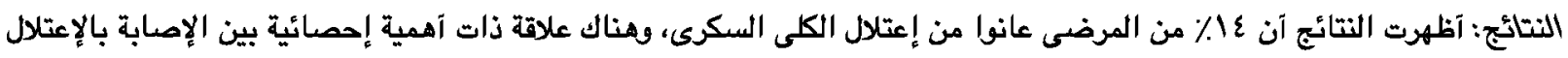

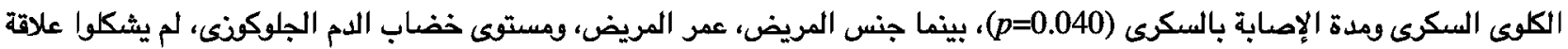

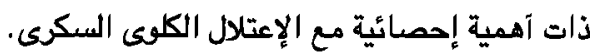

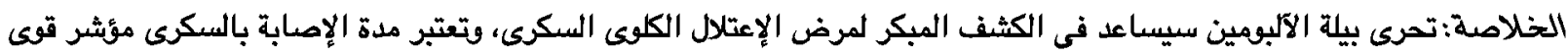

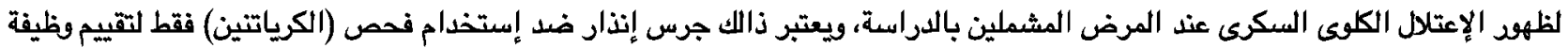

